\title{
Some Observations on the Materials and Implements of Design, Especially in Connection with Architecture
}

\section{The late T. Rickman}

To cite this article: The late T. Rickman (1847) Some Observations on the Materials and Implements of Design, Especially in Connection with Architecture, Archaeological Journal, 4:1, 14-20, DOI: $10.1080 / 00665983.1847 .10850645$

To link to this article: $\mathrm{http}: / / d x$. doi.org/10.1080/00665983.1847.10850645

曲 Published online: 06 Dec 2014.

Submit your article to this journal $\pi$ 
SOME OBSERVATIONS ON THE MATERIALS AND IMPLEMENTS OF DESIGN, ESPECTALLY IN CONNECTION WITH ARCHITECTURE.

THE following notes, relating to a subject of considerable interest both to the architect and the antiquary, have been extracted from the MS. collections of the late Mr. Rickman, which have come into the possession of Mr. Parker. They appear to have been composed as a communication to a provincial Architectural Society, chiefly with the view of engaging the attention of its members to the subject, and of eliciting more extended information "on the probable antiquity of the present implements of design." Some years have elapsed since this useful suggestion was made by Mr. Rickman, and, although various valuable facts connected with such researches have been subsequently made known, it does not appear that any archæological writer, in England, has hitherto bestowed upon the subject the attention which it appears to deserve. The remarks, however, of Mr. Rickman may be regarded with interest by many of our readers, and they are here offered for their perusal, not as affording fully detailed information, but in order to recall the attention of archæologists to a matter of interesting enquiry.

Surrounded as we are in the present day with mechanical inventions of the greatest delicacy, we are not often led to consider how those operations, now so greatly facilitated by various mechanical arrangements, were performed, at a time when these were deficient, and those materials which are now most common, were wholly unknown.

In the course of investigations necessary for the compilation of the third part of a paper containing the examination of Sir James Hall's Essay on Gothic Architecture, I had been forcibly struck as often heretofore with the total absence (so far as I had been able to find) of architectural designs made during that period in which the richest and most valuable examples of English architecture were erected, viz., the fourteenth century. Of this date we possess a variety of documents, manuscripts, fabric rolls, \&c., which belonged to our monastic and other institutions, having been preserved amidst 
the various revolutions which occurred during the reign of Henry VIII., and the intemperate scenes of the succeeding century. We might reasonably suppose that if the same arrangements had then been made previous to the erection of buildings, that we are now accustomed to make, some one at least of the numerous designs which must have been prepared would have been preserved to the present day.

I know not that any cause has hitherto been assigned for the absence of such documents, but the nature of the materials employed in ancient times may, as it has appeared to me, supply a probable explanation.

The implements of design may be described as follows.

Those substances, such as paper, \&c., on which the design is delineated; those substances which are used for marking the necessary lines on the tablet to be drawn upon; and the substances or means employed to efface or destroy erroneous or superfluous marks from the tablet. To these might be added, the mechanical arrangements to facilitate the production of the necessary lines.

In regard to the substances which were in use in Greece and the east, the information which we possess, though pretty clear as to writing, gives us no distinct idea with respect to drawing or designing. The Abbe Barthelemy, describing in the travels of Anarcharsis every authenticated matter connected with Greek literature, speaking of a Greek library, does not make mention of any tablet or other preparation proper for the delineation of diagrams, though he pays considerable attention to the article of paper.

We may however fairly suppose from incidental observations, that the following substances were used by the Greeks for purposes analogous to design.

1st, stone tablets.

2ndly, preparations of wood.

3rdly, the papyrus.

4thly, linen stretched.

5 thly, brass plates and perhaps plates of lead.

6 thly, the waxed tablet.

Of these it must be obvious that the greater part were not at all adapted for ordinary use. Stone tablets could only be serviceable to any extent, considering the cost of preparing them, when a design engraved on them was intended permanently to remain, and stretched linen would be liable to nearly 
the same objection. The papyrus, the common material for writing, was by no means proper for drawing designs at large, even if its size had been suitable, or its price such as to make it generally attainable.

The waxed tablet and metal plates might be useful for small drawings, but we can hardly conceive it practicable to have employed them of a sufficient size to make the working drawings for buildings yet remaining in Greece.

There remain therefore only the wooden boards or tablets, on which we may suppose that the Grecian architects drew their working designs, and it is obvious that this would be in most instances the means most easily available, as well as best adapted for such purposes of those at that time attainable. There are perhaps few parts of the globe in which something of the nature of chalk or bole may not be procured, and it is easy to conceive how in this mode the Grecian architects might manage their working drawings, for any erroneous marks made by a substance of that description would be easily effaceable merely by a wet cloth.

Whether the Roman architects employed similar means I know not that there is any distinct evidence; but the numerous discussions which have arisen concerning various passages in the writings of Vitruvius, from the want of drawings attached to his work, give us reason to suppose that the Romans had not adopted the delineation of plans and other drawings on the substances used for the composition of their books.

We may now turn to that period which more immediately concerns us, and consider the implements and materials which may be supposed to have been in use in the reigns of the three first Edwards. For writing a substance had been generally brought into use remarkably adapted for permanency, I mean the preparations of animal skin, such as vellum or parchment; but, though many manuscripts contain valuable illustrations of the costume of that time, and in some instances exhibit, so to speak, elevations of buildings, yet there is nothing that I have been able to find analogous to direct planning, or that description of drawing which can alone be useful in understanding the intentions of an architect, namely, the details of working drawings or even geometrical elevations.

It appears that in addition to vellum, a description of paper was introduced from the east soon after the commencement of 
the fourteenth century, but, from the great sums paid for books, and the distant parts from whence it was procured, I think there is little reason to suppose that it was ever supplied at such a price as to have been used as paper now is ${ }^{\mathrm{a}}$.

That the artificers of the thirteenth and fourteenth centuries were conversant with means of working in wood, we have abundant valuable proofs in the multiplicity of carvings yet remaining; there can be no doubt that they must have been well acquainted with various modes of smoothing wooden surfaces; and though I have not been able to ascertain the exact period at which plumbago was first used as a material for marking, there can be no doubt but some of the marking substances, which almost all parts of the kingdom produce, were well known at that timeb.

If once we admit the probability that tablets of wood, and chalk, a leaden plummet, or other marking substances, composed the chief implements of design, used by ancient architects, we shall I think find an easy mode of accounting for that absence of designs which has been noticed. It is clear, that even supposing that, in order to give the degree of permanence to some of the drafts which it was absolutely necessary that the ground-plan and some other general designs should have, those particular designs were drawn with some sharp instrument, so as to impress them as it were on the substance of the wooden tablet, the tablets when the construction was executed would only need the operation of smoothing to receive a new design, or, as is still more likely, the piece of wood which had exhibited the design would be put to some use which would effectually destroy the design impressed on it; and there is the more reason to suppose this has been the case, because those woods which alone could be made use of for this purpose are in themselves of no great permanence.

The only ancient design now extant, as I believe, in England, is of a date after the introduction of printing. This is preserved in the British Museum, and has been engraved in Lysons' Magna Britannia, in the history of the county of Cambridge. It is a design for a tower, which appears to have been intended to be added to King's college chapel, Cambridge, and it is I believe on paper; it is not very excellent in composition, though certainly valuable as an ancient design.

$$
{ }^{2} \text { See note A. }
$$

b See note B.

vor. IV. 
A carving in the spandrel of an arch at Worcester cathedral, appears to deserve especial notice, in connection with the subject under consideration. It is figured in Carter's Ancient Architecture, and represents an architect, who, having drawn his design on tablets, is presenting them to an ecclesiastic, probably the superior of the monastery. The figure given by Carter is so small that it is not easy to make out anything from the draft on the tablets, but if any proportion was observed, it seems clear that the tablets must have been of wood, or the abbot could not hold them as he is there represented. It is curious however, that the architect has also what appears to be a roll of old parchment; its breadth is such compared with its length that it seems very probable it is a description of the work to be done, or something in the nature of an estimate. The architect also has in his hand something which appears like a bevel square, but the representation of it is so rude, that one can hardly draw any conclusions from it. This piece of carving is, so far as I know, the only direct evidence we have on the subject; there may however be examples of the same kind in other places, as also in some ancient MSSe.

There is a citation in the account of Roslyn chapel in Britton's Architectural Antiquities, which may deserve notice, as tending to corroborate the idea that wood was used by ancient architects for the original designs. It is taken from a MS. memoir of the house of Douglas, in the Advocates' library at Edinburgh. It runs as follows, speaking of the founder, William Saintclair, earl of Orkney.

"The fundation of this rare worke he causd to be laid in the year of our Lord 1446. And to the end the worke might be more rare, first he causd the draughts to be drawn upon Eastland boords d, and made the carpenters to carve them, according to the draughts theron, and then gave them for patterns to the masons, that they might therby cut the like in stone."

Our principal marking materials at the present time are the useful China or Indian ink, and portions of plumbago set in cedar: of the antiquity of these substances I have been unable to ascertain anything at all conclusive. With regard to the means employed for effacing erroneous lines, mention is made of the crumb of bread, by some early Italian writers, but this

c See note C.

d Deals of wainscot, and timber for various purposes, imported from the Baltic, and termed "Estrichborde, Estregbords," \&c.-Pegge, in Anonym. Kennett's Glossary. 
or any other expedient has been superseded by the general use of a foreign production, the caoutchouc, or Indian rubber. Of the introduction of this very valuable material, the following extract from the preface to Priestly's Perspective, published in 1770 , gives as positive a date as we can well expect.

"Since this work was printed I have seen a substance excellently adapted to the purpose of wiping from paper the marks of a black-lead pencil. It must therefore be of singular use to those who practise drawing. It is sold by Mr. Nairn, mathematical instrument maker, opposite the Royal Exchange. He sells a cubical piece of about half an inch for three shillings, and he says it will last several years."

\section{NOTES.}

A. The date of the invention of parchment has not been precisely ascertained, but it dates from times prior to the age of Herodotus; the substitution of the skin of the calf for that of the sheep, forming vellum, was probably an improvement of a more recent period. In England in earlier times the use of papyrus, as also of the Oriental paper made of cotton, was unknown, and parchment was exclusively employed. The earliest fabrication of paper from linen rags, originated probably by the cotton paper used in the East as early as the ninth century, has been attributed to the twelfth century. The most ancient document on such paper known to exist, according to De Vaines, appeared to be a German charter, dated 1239; a letter exists amongst the records at the Tower of London, addressed to Henry III., and written previously to 1222 , which appears to be upon strong paper of mixed materials. Several letters of the following reign, preserved in the Tower, are evidently written on cotton paper. Paper was first manufactured in England by John Tate, the younger, of Hartford, at the close of the fifteenth century.-See Meerman, Obs. de chartæ lineæ origine, ed. Van Vaasen, 1767; Dom de Vaines, Dict. de Diplomatique; Gough's notices of Paper, Archæol., vol. viii. p. 158; three valuable remarks by Mr. Ottley, Archæol., vol. xxvi. p. 69, and Herbert's account of Tate, the first English paper maker, Dibdin's Typ. Ant., vol. ii. p. 320.

B. As it is certain that the ancients made use of common lead for the purpose of ruling lines, it seems highly probable that architects or designers might have adopted the use of the same convenient means of producing working drawings. The scribes used a small round plate of lead, which was found more convenient than a leaden style, being less liable to become 
bent, or to cut the parchment. Their plummets were termed, in Greek,

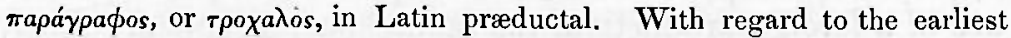
use of carburet of iron, commonly called black-lead, for a similar purpose, it may be observed that Professor Schonemann has asserted that the MS. of Theophilus in the library of Wolfenbuttel exhibits lines ruled with a blacklead pencil. It is attributed to the twelfth century. Conrad Gesner, in his treatise on fossils, (Zurich, 1565,) described pencils for writing formed of wood with a piece of lead, or as he believed, an artificial composition, called by some, "Stimmi Anglicanum." He gave moreover a woodcut representation of such a pencil. From the writings of subsequent authors of the sixteenth and seventeenth centuries, it is obvious that the use of so convenient a material for the purposes of artists and draftsmen became more generally known; and in Italy, it was designated as Flanders stone, having been introduced from the Netherlands. Further information on this subject may be obtained from Beckmann's History of Inventions.

C. Since the time when these observations were penned by the late Mr. Rickman, it does not appear that any examples of architectural working drawings have been brought to light in our own country. In relation, indeed, to a period somerwhat later than the middle-age times to which his attention was chiefly addressed, the collection of valuable designs, plans, and elevations, designed by an architect of the Elizabethan age, John Thorpe, may deserve especial notice. It is now preserved amongst the collections of the late Sir John Soane, and a description of the curious contents of the volume is given by Dallaway, in his edition of Walpole's Anecdotes of Painting, vol. i. p. 330. On the continent, however, a few medieval architectural designs and working drawings have been preserved, of great interest. The existence of the original designs of Cologne cathedral, attributed by Boisseree to the genius of Master Gerard, the director of the work commenced by Archbishop Conrad in 1248, is now well known, as forming the authority upon which that noble structure is at the present time in course of completion. The designs and plans which served for the construction of another fine example of ecclesiastical architecture in Germany have recently been discovered, and their publication may speedily be expected. I am indebted to Monsieur Tastu, one of the curators of the library of Ste Genevieve, at Paris, for the inspection of a most valuable evidence of a similar nature. It is a portion of a very large architectural drawing upon parchment, which exhibited the western elevation of a magnificent example of church architecture in the south of Spain, in the most florid Decorated style. 